Vox Patrum 6/1986/z.10

\title{
MĘCZENNICY WCZESNOCHRZESCIJAŃSCY W WYKŁADACH LOZAŃSKICH A. MICKIEWICZA
}

Micklewtcz, zywy świadek męczeńskich dziejów Polski, w przedmowle do "Dzladów" części III zadedykowanych "Narodowej sprawy męczennikom ... zmarłym w Archangielu na Moskwie-w Petersburgu" pisał: "Polska od pół wieku przedstawia widok z jednej strony tak clągłego, njezmordowanego 1 nieubłaganego okrucieństwa tyranów, z drugiej tak nieograniczonego poświęcenta się ludu 1 tak uporczywej wytrwałości, jakich nie było przykładu od czasów prześladowania chrześcijaństwa. Zdaje się, ze królowie maja przeczucie Herodowe o zjawieniu się nowego śwlatła na ziemi 1 o bliskim swoim upadku, a lud coraz mocniej wierzy w swoje odrodzenie się 1 zmartwychwstanie ...". Zaś postawa filomatów 1 filaretów podczas procesu - dodawał poeta - miała wobie "coś mistycznego 1 tajemniczego", a zdarzenia z nimi zwiazane "zdaja się przenosić czytelników w czasy "dawne, czasy wiary $i$ cudówn ${ }^{1}$.

Blisko szesnaścle stulect dzieliło wydarzenta okresu plerwszych wieków chrześcijaństwa 1 tragedil Polsk1. Jaki musiał byé więc ogrom clerpjenia 1 ponizania Polaków przez wa carskie z jednej strony, a bohaterski tch opór z druglej, skoro poeta przeprowadzil analogie do czasów Nerona 1 Dloklecjana, za panowania których prześladowanie chrzéscijan osiagnęło szczyty swego okrucieńs:wa. Idea męczeństwa starozytnych chrześcijan nie była więc cakkiem obca Mickiewiczowi. Przebywajac dwukrotnie prymie w latach 1829-1831 oddychał atmosfera katakumb 1 Koloseum ${ }^{2}$, a w Je-

1 Dz1eła. Utwory dramatyczne/wyd. jublleuszowe/, Warszawa 1955, III 123, 125 .

2 Rzym wywarł na Mlckiewiczu ogromne wrazenle, a szczególnie jego zabytk1. W liście do Frano1szka Malenskiego z grudnia $1829 \mathrm{r}$. /Tamze, XIV 506-507/ pisal: "Rzym mnie zagluszył 1 kopuła S.P1otra nakryła wszystkie pamiatki włoskie ... Przez Muzeum jeszcze tylko przemaszerowazem szybkim krokiem rzucajac tu 1 ódale oozyma, zatrzymujac sie ledwie przed Apollinem, Laokoonem 1 Zapánikiem. Marsz ten trwał dwie godziny. Gdybý́s zebral wozystkie po- 
go ks1яgozbiorze znalazły s1e m.1n. tak wybitne dzieła na ten temat, Jak apologia "Le génié du christianisme" /Paris 1802/ 1 epopeja chrześcijariska "Les martyrs ou le triomphe de la religion" /Paris 1809/ niemal współczesnego mu F.R.Chateaubrianda $/+1848 /{ }^{3}$, który waśnie w męczeństwie starozytnych chrzé́cijan widział siłe 1 piękno nowej religil. Główni bohaterowie jego epopei giną na arenie ampiteatru, a $1 \mathrm{ch}$ krew, jak głosił Tertulian, stawała sie posiewem nowych chrześcijan ${ }^{4}$, przyczyniając sie do triumfu wiary chrześcijańskiej nad walącym sie w gruzy śwlatem pogańskim. Nasz poeta nle poświęcl wprawdzie zadnego osobnego utworu poetyokiego wczesnochrześc1jańskim męczennikom, nie studiował bezpośrednio tak jak Chateaubriand źródeł martyrologicznych, lecz na $1 \mathrm{ch}$ temat wypowiedział się za pośrednictwem swego ulubionego poety Prudencjusza /348-406/, któremu pośw1ęc1ł ostatni z wygłoszonych mykładóm lozanskich, tzw. wykład instalacyjny. Mozna więo powiedziec, ze Mickiewicz patrzył na starozytnych męczenników ohrzesoijarskich oczyma Prudencjusza.

Wykłady lozanskie prowadzil poeta watedrze literatury laciŕskiej na akadem11 Lozannie od 2 XI $1839^{\circ}$ do 26 VI 1840 roku.

sag1 1 gipsy drezdeńskie, weneckie, nawet florenckie, schowarby je katku Watykanu. Tutejsze Muzeum jest to prawdziwe miasto posągów, zawalone sarkofagami 1 tynkowane inskrypcjami". Dwa mies1ące pótniej w lutym $1830 \mathrm{r}$. dzielik sie swoimi spostrzezentami z Józefem Jeżowakım/Tamże, 519-520/: "n starożtnym Rzymle chybabym pisał wierszami ... Dlaczegóz tu nie jesteś ze mna decyPrować napisy na trumnie, w której leża kośc1 Scypiona, przechadzac sie między tysiacami inskrypcj1, tak pięknych i czytelnych, Jak gdyby wczora wyrzezane by $ł y, 1$ widziec na obeliskach napisy Augusta 1 na Luku Tryumfalnym świeczn1k jerozolimsk1; Koloseum, którego 1 ten kawał muru, oceniony, kosztowałby dziś 19 milionón Pranków $\mid 1 !$ - nie ma sposobu tych wykrzykników zakończyén.

3 Por. ksiegozbiór poety znajdujący sie w Muzeum Literatury 1m. A.Mickiewicza w Warszawie. 0 wpływie Chateaubrianda na twórczośó Mi okiewicza pisal W. Bruchnalski, Mickiewicza "Dziady wileńskie" pobec Chteaubrianda powieśc1 "Atala" 1 "René", Lwów 1925; tenze, Paralele niektóre między "Panem Tadeuszem" a "Męczennikami" Chate aubrianda, Lwów 1936.

4 Por. Tertulian, Apologetyk 50, РОК 20,202. 
Miejscowa Rada Oświecenia Publicznego powodowana europejgkim rozgłoeem Mickiewicza, cieszącego sie opinią jednego z największych 6rczesnyoh poetów, powierzyła mu w charakterze zajęć zleconych wykład 11teratury łacińskiej okresu augustowskiego ${ }^{5}$, mianując go najpierw profesorem nadzwyczajnym, a nastepnie 13 III 1840 r. profesorem zwyczajnym akademi1 lozanskiej ${ }^{6}$. Mimo wyznaczonego tematu Mickiewicz nie zdazył omówić okresu augustowskiego podczas 30 wykładów wygłaszanych dwa razy w tygodniu, ale tylko okres przedaugustowsk1, jako wstęp do właściwego tematu ${ }^{7}$. Podczas wykładów prowadzonych - Jezyku francuskim przytaczal z pamięci, w oryginale, długie niekiedy ustępy z dziel omawianych autorów, analizował 1ch treść, styl 1 Język, porównywał $1 \mathrm{ch} z$ pisarzami nowozytnymi, " czym przewyzszy 1 Byrona 1 Goethego, zadziwiając wszystkich doskonałą znajomośc1a Jezyka łacińskiego. Podczas przygotowywania się do nich czytaz kilkakrotnie teksty oryginalne, a póńniej z pamięci czynił z nich notatki. Było to jednak przyczyna wielu nledokładności, rozbiezności, niepełnych cytatów, ale podobnie cytowali równiez Montesquieu, Bacon 1 Byron. Micklewicz korzystał takze ze współczesnych sobie podręcznikó, a przede wszystkim z ostatnio wówczas wydanej histori1 literatury J.Ch.F.Buhra ${ }^{8}$. Wykłady wygłaszał z pamięc1, będac doskonałym 1mprowizatorem 1 artystą. Zapalał serca 1 umysły słuchaczy.

Po promocji na profesora zwyczajnego zobowiązany był wygłosić w obecnośc1 władz kantonu 1 akademi1 oraz studentów tzw. wykład Instalacyjny; miał to być poniekąd wykład popisowy. Jego termin wradze wyznaczyły na 26 czerwea 1840 r., tuz po zakończeniu zajęć akademickich $/ 20 \mathrm{VI} /$. Jako temat wybrał poezje wczesnochrześcijańska

5 Tytuł urzędowy wykładów brzmiał: "Histolre littéraire du siècle d'Auguste, accompagnée de l'explication de morceaux cho1sis'des auteurs de ce siecle.

6 Por. Nouvelliste Vaudols z $25 \times 1839 \mathrm{r}$.

7 Rękopis wykładów lozańskich obejmuje 210 stron pisanych na kartach róznego formatu. Zestawił je, uzupeinil 1 wydał prof. Jerzy Kowalgk1. Por. A.Mickiewicz, Dzlela wszystkie/wyd. sejmowe/, Warszawa 1936, VII /omaw1ając wykład Instalacyjny będe posługiwała sie tym wydaniem/. Z 30 wykładów w rękopisie zostało utrwalonych tylko 10, łacznie z instalacyjnym.

$8 \mathrm{~J} . \mathrm{Chr}$. Bahr, Geschichte der r bmischen Literatur. Supplement-Band: Dio christifch-rلmische Literatur. Abt. 1: Die christilichen Dichter und Geschichtsschreiber, Carlsruhe 1836, s.VIII + 159 /Tertulian s.17-18, Laktancjusz s.17-18, Prudencjusz 41-49/. 
1iustrowana pismami Prudencjusza. Poniewaz kilka dni wczéniej poeta zapowiedział wykłady na rok 1840/41 o schyłkowym okresie 11teratury łacińskiej, czyli przede wszystkim chrześcijańskiej, więc wykład ten pomyślany był jako wstęp do przyszłorocznego kursu 1 miał zachęcı́́ zainteresowanych słuchaczy. Przyjęto go z duzym entuzjazmem $^{9}$. Mickiewiez jednak nie rozpoczłł zapowiedzianych wykładów, gdyz we wrzesniu tegoż "samego roku objał kurs języków 1 literatur słowiańskich w Kolegium Francuskim. Opuścił więc Lozannę 1 wyjechał do Paryża.

Przeglądając prozaiczne pisma poety zauważym, ze problematyka łacińskiej literatury wczesnochrześcijańskiej była mu znana. Wymienia bowiem jej głómnych przedstawicieli, których otwarcie nazywał Ojcami Kościoła oraz lch zasługi zarówno wobec jezyka actískiego, jak 1 autentyzmu chrześcijańskiej wiary. Juz w piernsych wykładach lozańskich bronił łacjny, podkreślał, że jej przedłuzeniem są pisma 0jców Kościoła, które stały się wzorem późniejszej wymowy kościelnej. Wskazywał na wkład św. Augustyna 1 Tertuliana w rozpowszecinianie łaciny w Kościele. Szczególnte ten ostatni, jak stwierdził, "wytworzył łacinę pospolitą, która jednakowoz wcale znacznie przewyższa lacı́nę klasyków" ${ }^{10}$. Idąc zaś za podręczni-

9 Sala na I piętrze starej akademil, mogazca pomieścić do 50 osób, była pełna. Byli na niej obecni: Rada Oświecenia Pulicznego $i$ akademia z propesorami nadzwyczajnymi 1 honorowymi. is vykładzie prezydent lady De la Harpe wręczył Mickiewiczow a dyplom nominacyjny 1 wygłosił przemówiente. Przemawiał równiez rektor akademii C.Monnard, zachęcając go, by jak najdłuzej pozostał w Lozannie. Wiadomości o tym wykładzie dostarczają nam autobiograficzne zapiski, sprawozdania dziennikarskie, listy samego Mickiewicza /z 2 i 17 lipca/ oraz wspomnienie Włocha M.J.Scorazziego i L.Orpiszewskiego. Od Scorazziego wiemy, np., ze wykład był stenografowany przez M.Duranda z Lozanny. Poniewaz Rada ośriecenia domagała sie opublikowania tego wykładu, Mickiewicz uzupełnił go później ogólnym wstępem, a syn poety Władysław połączy $¥$ całość 1 wydał, zaś jego przekład polski postarał sie P.Chmielowski. Por. Adam Mickiewicz, Odczyty wozannie, Warszawa 1885.

10 Por. IV wykład lozański, w: A.Mlckiewicz, Dzleła wszystkie/wydanie sejmowe/, Warszawa 1936, VII 282: "wszyscy wiedza, ze łacina była językiem urzędowym teologów, że znajdujemy wzory pymowy czy to w systematycznych działach ojców Kościoła, czy tez w 1ch kazaniach. Czytanie tych ksizżek przyniosłoby korzyść bezpośredniaz; /.../ Przede wszystkim jednak wazne i poniekąd niezbędne jest studjum łaciny dla wyuczenta s1ę sztuki pisania, dla kształtowania stylu. Słowo pisane, styl, sa tworem 
kiem Bahra, przyjmował ustalony przez Izydora z Sewill1 /+ 635/ podzial piémiennictwa rzymskiego na jezyki: starodawny, rzymski 1 mieszany ${ }^{11}$.

Zgodnie z ówczesnymi przekonaniami, Tertuliana $i$ Laktancjusza - prozalkóm literatury lacińskiej - zaliczył poeta mylnie do przedstawicieli poezji chrześcijańskiej, któraz mieli się posługiwać w rozpowszechnianiu wiary 1 zwalczaniu swych przeciwników ${ }^{12}$. Gdy późnıej znalazł się w Paryzu, równiez wiele czasu poświęcał lekturze pism 0jców Kościoła. Wiemy, że już wcześniej nosił się z zamiarem przełozenia na jezyk polski "Wyznań" św. Augustyna 1 innych dzieł 0jców, które miały powiększyć tworzonaz przez B.Jańskiego b1blloteczke dziel budujacych ${ }^{13}$. W wykładach paryskich wymienia takze Innych 0joow Kościoła - św. Ambrozego, d́w. Buzebiusza 1 św. P1otra Chryzologa, których zywoty znał przede wszystkim Brewiarza rzymskiego. W tych trzech postaciach dostrzegaz emanujacy autentyzm zyc1a chrześcijańskiego ${ }^{14}$. Powyzszo wzmianki świadczą, ze Mickiewicz

rzymskim. Rzymianie przyswoili sobie wszystkie formy greckie. Ze S.Augustynem 1 Tertulianem wszedł później Wschód /tzn. chrześcijaństwo/. On to wytworzył racine pospolitą, która jednakowoź wcale zn znie przewyzsza łacinę klasyków /.../ 285: Lacina jest więc językiem prawa. Jest również językiem teologj1, przez 0jców Kościoła łacińskiego". Por. także wykład V, tamże 289.

11 Por. Szkice wykładów lozańsk 1 ch w oparciu o podręcznik Bahra /8.17-19/, dz.cyt., VII 283.

12 Por. wykład 1nstalacyjny, tamze, va 7-338: "Wszyscy autorow1e poezj1 chrześc1jańskiej pisanej naleza w istocie, począwszy od Laktancjusza 1 Tertuliana, do rzędu filozofów 1 retorów. Prowadzac polityke religijnz, posługiwali sie poezja, by rozpow8zechniać swoje nauki, lub by ude aać na nauki przeciwników."

13 Por.l1st Semenenk1 do Jańskiego z 9 III $1838 \mathrm{r}$. w: A.Mickiewicz, Dz1exa wszystxie /wyd. sejmowe/, Warszawa 1933, XVI 516: "Wyznania é.Augustyna $N$ tymże, czy nieco późniejszym czasie powział Mickiewicz zamiar przełozenia tego dzieła. Gdy z początkiem $1838 \mathrm{r}$. B.Jański zawiazaz ścíślejsze grono w celu rozpowszechniania dziel budujących, 1 kiedy h iadano plan potrzebnych tiumaczen, Kajsiew $1 \mathrm{cz}$ naw lazal do tego dawnego zamiaru/ Adamow1 pisaz - przypominamy "Konfesje" s.Augustyna, 1 w ogóle dobrzeby było ojców/Kościoła/ nie przepomnieć".

14 Por. IV wykład paryski o literaturze słowiańskiej z 16 I 1944 •. w: A.Mickiewicz, Dzieła/wyd. Jublleuszowe/, Warszawa 1955, XI 365-366: "Czytajcie b. larz rzymsk1 na miesiąc ubiegły. Ambrozy, rzymski urzędnik, zołnierz, przybya do Mediolanu dia uspokojenia zamieszek. Pachole woła, ce należy go ogłosić arcybisku- 
zajmował się szczególnie wczesnochrzé́cijańska literatura łacińską, gdyż o greckiej nie znajdujemy u niego zadnych wiadomości. Ojcowie interesowall go zwraszcza jako przedstawiciele jęzka łacińskiego 1 kontynuatorzy kultury lacińskiej, choć dostrzegał równiez w ich twórczości prawdziwe wzory chrześc1jańskiej wiary.

Majac takie nastawiente do literatury patrystycznej, Mick1ewicz cały kurs wykładów zamierzał poświęcić łacińskiej poezj1 wczesnochrześcijańskiej, która nazywał literatura schyłku. T pierwszej części wykładu instalacyjnego charakteryzuje ja krótko, ukazujac jej założenia 1 cechy. Przypomina, że poeci tego okresu studiowal1 Wergiliusza, Horacego 1 Cycerona, by uchwycić tajemnice sztuki, dzlęki której ci klasycy cieszyli się wielká poczytnościz. W miejsce mitycznych teogonil wczesnochrześcijańscy poeci chcieli dać poetycka Księge lodzaju, a epopeje Homera 1 Wergiliusza zastapić epopejami ewangelicznymi. Wszyscy oni starali się ponadto zachnwać formy stylu klasycznego, w czym przewyższali współczesnych sobie autorów pogańskich. Ale ten właśnie sztuczny klasycyzm, "ubieranie" twórczości w metra klasyczne znacznie krępowal - zdaniem Mickiewicza - natchnienie poetyckie 1 przyémiewal treść ewangeliczna, nie wystarczając do wyrazenia tajemnic nowej religii ${ }^{15}$. Nie było jeszcze tego rodzaju sztuki chrześcijańskiej, a stworzył ja dopiero Prudencjusz Klemens ${ }^{16}$.

pem; lud powtarza ten okrzyk. Biora Ambrożego, podnoszą na rękach, obwołuja arcybiskupem. Człowiek ten nie był Jeszcze ochrzczony, później stał sie ozdoba, doktorem Kościoła /.../. Swięty Euzebiusz, którego zywot czytamy w brew1arzu takze w grudniu, nikomu w swej diecezji nie znany, został równiez nagle obwołany przez lud biskupem". Simul ac viderunt, probaverunt"; ledwie go ujrzel1, uznali w nim świętego/.../. W świętym/Piotrze/ Chryzologu rozpoznał świety Sykstus papiez, człowieka, którego raz widzial we śnie 1 mianował go biskupem".

15 Wykład instalacyjny, dz,cyt., VIII 338-339.

16 Tamże, 339: "W tym stanie rzeczy sztuka chrzé́cijańska jeszcze była nie powstała. Natchnienie liryczne szukało jeszcze rytmu, strof 1 melodyj, które nadawałyby sie dla niego, a równoczénie czyniły zadość wymogom sztuki. Z drugiej strony styl uczony szkoły doktorów kruszył się 1 popadał rozkład, ponieważ nie wystarczał juz więcej dla wyrażenta wszystk 1 ch tajemnic, zawartych w Nowem Słowie. By stworzyć sztuke chrześcijanską, potrzeba było poety, który połaczyłby święe natchnienia wyznawcy z wiedza filologa. Sława ta nalezy do Prndencjusza Klemensa, poety czwartego wieku naszej ery". 
On był, według Mickiewicza, twórca poetyckiej sztuki chrześcijańskiej 1 jemu to włánie poświęca niemal połowę swego wykładu instalacyjnego. Ten hiszpansk $\mathrm{z}$ pochodzenia poeta odpowiadał naszemu wieszczowi przede wszystkim dlatego, gdyź widział w nim wiele cech romantyka, jak bezpośredniość, prostotę, lekceważente form klasycznych. Interesował go przejawiajacy się wego poezji realizm hiszparíski, lubujący sie $w$ jaskrawych obrazach, w przedstawianiu krwawych kaźni męczenników, przypominających późniejsze obrazy tortur 1 rzezi malowane przez J.R1berę/1590-1652/, które sam nazywał "przerazająca energia" oraz włączanie do pieśn1, zwłaszcza o męczennikach, wątków legendarnych tak bliskich romantyzmowi. Osobie Prudencjusza poświęcił w wyładzie zaledwie kilka zdań ${ }^{17}$, mimo ze Bahr, z którego korzystał, podawał bardzo obszerny zyciorys poety ${ }^{18}$. Nie wyliczył równiez wszystkich jego dzieł/Cathemerinon, Liber Apotheosis, Hamartigenia, Psychomachia, Contra Symmachum, Peristephanon, Dittocheon seu Tituli historiarum $/^{19}$, ale przystapił od razu do omawiania 1 cytowania tylko trzech, najbardziej mu bliskich - a mianowicie Contra Symmachum, Cathemerinon, które tłumaczy Jako "Hymny powszednie" oraz utworu reristephanon $/ 0$ wieńcach $/$, uznanego przezeń za najpiekniejszy 1 najbardziej wzruszajacy ${ }^{20}$. Ale 1 w tym doborze anal1zowanych Pragmentów kierował się głównie kryterium dramatyczności. Wybierał bowiem te urywki, których treść mogła przykuć ưage słuchaczy. Streszcza więc najpierw dług1, liczący blisko

17 Tamze, "Żywot Prudencjusza jest otoczony nieprzeniknionymi tajemnicami. Nie znamy daty jego urodzenia, ani roku jego śmierci. Wiemy jedynie, ze w młodości spełniał ważne czynności konsula, czyl1 zarządcy prowincji. Zawód poetycki zacząz wieku późniejszym. Z początku układał poezje przepełnione alegorjami, a zalecające się jedynie czystościa języka".

18 Bahr, dz.cyt., 41-49.

19 Wrzystkie pisma Prudencjusza zostały ostatnio wydane krytycznie przez P.M.Cunninghama, Aureli1 Prudentii Clementis Carmina, Turnholt1 1961/CCL 126/. Polski przekład: Aureliusz Prudencjusz Klemens, Poezje. Wstęp, opracowanie 1 tłum. Mieczysław Brożek, PSP 45 /w druku/. Za udostepniente maszynopisu serdecznie dziskuile ks.doc. drowi hab. Emilowi Stanul1.

20 Wykład instalacyjny, dz.cyt., VII 342: "Lecz najpiękniejsze bezsprzecznie z dzieł Prudencjusza to "Księga o Wieńcach", czyli "W1eńce", lub raczej "Wieńczenia Mączenników", poezje poświęcone chwale męczenników". 
1810 w ierszy, poemat - apologię "Przeciw Symmachowi" poświęcony głównemu szermierzow1 ginącego pogaństwa, który jeszcze upominał się o przywrócenie posagu Wiktoril w senacie. Chcąc jeszczé bardziej udramatyzować obraz, przytacza tylko sparafrazowany początek poematu, oparty na Dziejach Apostolskich /28, 1-5/, opowiadający jak to f́w. Paweł, po rozbiciu okrętu,wyrzucony na Maltę, usłłował się ogrzać przy ognisku 1 został ukąszony w rękę przez żmiję, która wyskoczyła z palących się gałęz1. Sw. Paweł ze spokojem odrzucił gada w płomienie ${ }^{21}$. Moźna przypuszczać, ze ten ep1zod przytoczony przez Míckiewicza mógł zroblé wrażente na słuchaczach.

Najwięcej jednak efektów dramatycznych mógł się spodziewać przy ukazywaniu męczeńskich scen starożytnych chrześcijan, whóre obfitowała twórczość Prudencjusza. Z dotychczasowych studiów Mickiewicz wiedział o prześladowaniu i szkalowaniu chrześcijan, słyszał nawet o liście Pliniusza Młodszego, który pyta cesarza Trajana czy ma prześladować napotkanych chrześcijan, oraz o wzmance Swetoniusza, przypominającej późniejsza rzeź niewiniątek ${ }^{22}$. Wiedział równiez, że przez trzy pierwsze wieki poganie die rozumiejąc tajemnicy eucharysti 1 posądzali 1 oskarżali chrzescijan o to, ze na swych zgromadzeniach piją krew ludzką, z którym to zarzutem walczyli już apologeci. Bliska mu była postawa torturowanych 1 mordowanyc: chrześcijan, wierzących niezachwian? a prawdziwego Boga. Zgodnie ze swym zwyczajem porównywanta faktón, wiązał Mickiewicz nierzadko dawne sytuacje z sobie współc7 asnymi ${ }^{23}$. W postawie męczen-

21 Contra Symmachum I 1-89, CCL 126, 182-185, u '⿺1 ck1ewicza - $\pi y-$ kład Instalacyjny, dz.cyt., 341 .

22 Por. Jego Rozmowy z Chodźkaz/19 IV 1847/, w: A.Mickiewicz, Dzieje wszystk1e /wyd, sejmowe/ XVI 231: "Najciekawszym 1 jedynym pomnikiem chrześcijańskim po Rzymianach jest list Plinjusza do Trajana 1 odpowied $i$ tego ostatniegc. Wazna takze jest rzecz w Swetoniuszu /o tradycji podobnej rzezi dzieci przez Heroda/".

23 Tamże: "Dzisiaj podobniez się dzieje. Rosja nikogo się nie lęka, oprócz idei polskiej. Żaden ze słuzących Rosji Polaków, nawet najbardziej spodlonych, poddający się ciałem i słu. ‘cych wiernie, nawet męczących współziomków, sercem i duszaz Moskalem sie nie taczy. Ale Polacy dzisiejsi jej/idei polskiej/nie stawia 1 sa względen ilosjan tem tylko, czym byli przedchrystusowi żydzi względem Rzymian". 
ników Idących za wzorem męczonych apostołów 1 kamienowanego, ale wpatrzonego wiebo św. Szczepana, upatrywał s1łę rozrastającego sie chrześcijaństwa ${ }^{24}$.

Po scharakteryzowaniu traktatu "Contra Symmachum" przechodzi Mickiewicz do omómienia drugiego dzieła Prudencjusza - "Cathecurinon", zawierającego dwanaście hymnów 1 pieśni na pory dnia 1 różne uroczystości kościelne. Charakteryzuje je krótko ${ }^{25}$, na ogó 1 bez cytowania tych utworów. Przytacza z nich jedynie po łacinie 1 tłumaczy po polsku Pragment XII pieśni - Hymn na Trzech Króli - dotyczący rzezi niewiniaztek:

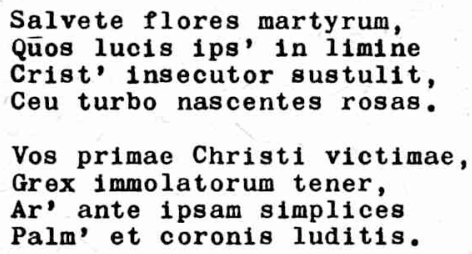

24 Por. IV wykład paryski, w: A.M1ckiewicz, Dzieła/wyd. jubil./ XI 367-3 ?: "Ale Jak opisać wizerunek nowych synów Kościoła przyszłośc1? Przypatrzcie się dziełom sztuki. Przedstawia się w nich dostojne oblicze świętego Piotra 1 świętego Pawła 1 świętego Szczepana/.../ Głowy ich błyszczą w ognistej koronie, a z ich dłont bija snopy promient. Czy obeenie pomiędzy tymi, co dzí́ słuza Kościołow1, znajdzie się takie oblicza? /.../ S.Szczepan poglądał dumnie na tych, co go męczyli. Nie miał oczu spuszczonych w ziemie. Widział niebiosa otworzone 1 Syna Człowieczego, który go przyzywał ku sobie/.../Wtenczas dopiero stantecie się podobni do tych potęznych $i$ świetlanych postaci Kościoła pierwotnego".

25 Wykład instalacyjny, dz.cyt., VII 341-342: "Po ogłoszeniu satyr, styl Prudencjusza był juz ukształtowany, Prudencjusz opanował całkowlcie formę. Teraz spróbował nowego gatunku. Ułożył "Księgę hymnów powszednich", zbiór poezyj, k tórych rodzaj 11teracki trudno bliżej określić wyrażeniem szkolnem. Są to rozmý́lania 1 nastroje poetyczne. Poczqtek każdego utworu nie przedstawia nic szczególnie znamiennego i przypomina ody starożytnośc1. Lecz poeta chrześc1jański nie poprzestaje na za sowaniu obrazu, opisaniu poranku lub wieczora, ale stara się n knąć głębiej w przyrodą. Usiłuje uchwycić sens moralny kaźc go zjas. 3ka przyrody". 
"Cześć wam, płonki Kośc1 oła wojującego! o wschodzie Jutrzenk1 złamał was wróg Chrystusa, jak trąba powietrzna, unosząca róże ledwo rozkwitłe.

o piermsze ofiary za wiare, młodociana gromadko baranków na zabicie; w prostocie swojej igracie przed samym ołtarzem palmami 1 wieńcami, które was czekają".

Ta wspaniała fanfara inwokacyjna do męczenników jest jedynym Pragmentem z Prudencjusza, który Mickiewicz zacytował bez opuszczer ${ }^{26}$.

Kopalnię dramatycznych wątków znajdzie dopiero Mickiewicz w trzecim utworze Prudencjusza - "Peristephanon", najobriciej cytowanym,złożonym z czternastu pieśni ${ }^{27}$. W zwiazku ze warastającym kultem męczenników, poeta hiszpański chciał wprowadzić równiez do poezji starożytnych herosów chrześcijańskich wiejsce ich pogańskich odpowiedników. Sa to pewnego rodzaju epínikia, hymny na zwycięstwa odniesione w walce ze soba na wzór tych, jakie ongiś pisaz Pindar na cześć zapaśników greckich, prawdziwe śpiewy historyczne

26 Tamże, 343-344, CCL 126,69. W przekładzie M.Brozka Pragment ten brzmi:

"Cześć męczennikow kwiatom, czesć,

Które na samym progu dni

Chrystusa prześladowca zmiótz

Jak burza pierwsze pączki róz.

Z sług Chrystusowych pierwsze wy,

oflarne owce Jego trzód

Dziecinnie u ołtarza dziś

Palmą 1 wieńcem bawicie się".

27 Por. CCL 126, 251-389, tłum. M.Brozek, PSP $45 /$ w druku/:

1. Na cześć Emeteriusza i Helidoniusza

2. Na cześć św. Wawrzyńca

3. Na cześć męczennicy św. Eulali1

4. Na cześć osiemnastu męczenników Cezaraugusty

5. Na cześć męczennika Wincentego

6. Na cześć mezenników Fruktuoza, Auguriusza 1 Eulogiusza

7. Na cześć męczennika Kw1ryna

8. 0 miejscu męczeństwa 1 chrztu w Kalagurze

9. Męczeństwo Kasjana worum Korneliusza

10. Męczeństwo Romana

11. Męczeństwo Hipolita

12. Męczeństwo Apostoła Piotra 1 Pawła w Rzymie

13. Męczeńs two Cypriana

14. Męczeństwo Agnieszki. 
starożytnej gminy chrześcijańskiej układane w rozmaitych metrach w oparciu o podania, tradycje 1 legendy, początkowo ku czci męczenników hiszpaŕskich, a po odwiedzeniu Hzymu /402-403/, również rzymskich. W pieśntach tych, zbliżonych niekiedy do toku ludowej ballady, tchnących wielkim patriotyzmem, opisane są często całe procesy, przesłuchania 1 odpowiedzi męczenników, dołączone są upomnienia moralne 1 pouczenia dydaktyczne. Spośród tej obfitości Mickiewicz mybrał 1 zacytował w swym wykładzie pięć pieśni - wieńców: O Mawrzyńcu, Hipolicie, Helidoniuszu, Romanie 1 Eulali1. Przytaczal z nich 1 omawiał tylko wątki tchnįce największz ekspresją. Chciał niejako uzmysłow lé słuchaczom sceny chrześcijańskiej martyrologi1, w której na plan piermszy wysuwa sie nieznana tragedil starozytnej postać prokonsula rzymskiego 28 .

Przypomnijmy teraz sylwetki pięciu męczenników, których dramaturgię męczeństwa chciał Mickiewicz przybliźć swym słuchaczom.

Plerwszym męczennikiem, do którego odwołuje się w swym wykładzie Mickiewicz jest jeden z najpopularniejszych świętych rzymskich pochodzenia hiszpańskiego - diakon Wawrzyniec. Akta jego męczeństwa, jé́lı w ogóle istniały, zaginęły już przed IV wiekiem. Żywa była jednak tradycja jego męczeństwa, utrwalona w różnych Passiones 1 legendach hagiograficzny $\mathrm{ch}^{29}$, przypominana przez wielu ojeów Kościo-

28 Wykład instalacyjny, dz.cyt., 342: "M1mo pozorną jednostajność opowiadań 1 legend według akt męczeństw, nic bardziej urozmalconego, Jak sceny 1 charaktery osobistości w "Księdze o Wieńcach". Sceny jej odpowiadaja tyluź scenom jakiejś wielkiej tragedji. Ton 1 styl poety zmieniaja sie co chwila 1 dowodzą dojrzałości jego talentu. Pierwszy plan każdej sceny w tym ciazgu obrazów zajmuje prokonsul rzymski, osobistość nowa, nieznana tragedji greckiej, straszniejsza od Labdacydów 1 Atrydów. Wzór tego charakteru widzimy w Festusie 1 Feliksie z "Dziejów Apostolskich". Tacy byli moznowladcy Rzymu w owym okresie, tacy pojawiaja się u Prudencjusza, raz ponurzy 1 dzicy, raz weseli 1 bez troski, ale zawse butni, dowcipni i zimni".

29 Por. H.Delehaye, Recherches sur le légendier romain, AB 51 /1933/ 34-98, zwł. 49 nn. 
$\mathbf{1 a}^{30} 1$ starożytne martyrologia. Nie chcac oddać władzom cesarskim majątku kościelnego, a który jako diakon by $ł$ odpowiedzialny z polecenia papieza sykstusa II $/ 257-258 /$, mial on zostać spal ony na zelaznej kracie podezas rrześladowanta cesarza Waleriana $r .258^{31}$. Prudencjusz poświeca mu wientec, drugi wolejności, 1 drugi pod względem długości /584 w./. Mickiewicz tymczasem, pomimo 1z w swo1ch notatkach do wykładu miał aż 17 wierszy Prudencjuszowego "Trieúca", poświęca Wawrzyńcowi tylko dwa 1roniczne zdania prokonsula, stanowiace polskz pare- aze jednej tylko strofy: ${ }^{32}$

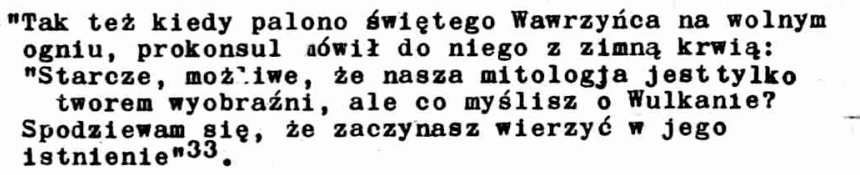

W całym poemacie hiszpańskiego poety nie ma mowy o mitologil, sędziá jest wim nazywany "prefektem królewskiego miasta", a nie prokonsulem, zaś męczennik "łotrem" /furcifer w. 317/ 1 "mysteriarchą" /w. 350/, a nie jak chce Mickiewicz "starcem". Wszystkie te szczegóły świadczą, ze wypowiedź Mickiewicza jest wolna parafraza wybranego fragmentu wiersza Prudencjusza, w która polski poeta wączył

30 Por. Ambrosius, De offic1is I 41; II 28; Epistola XXXVII 36-37, PL 16, 90-92, 149-150, 1139; Hymnus de $S$.: Lurentio, PL 17, 12541255. Augustinus, Sermo CCIV, PL 38, 1395-1396; Petrus Chrysologus, Sermo CXXXV, PL 52, 565-567; Leo Magnus, Sermo LXXXV, PL 54, 486; Maximus Torinensis, Homilia 75, PL 57,679-680; Damasus Papa, in: A.Ferrua, Epigrammata Damasiana, Citta del Vaticano $1942,166-167$.

31 Por. P.Franchi de Cavalieri, San Lorenzo e il supplizio della graticola, "Rømische Quartalschrift" 14/1950/159-170; S.Carlett1, S.Lorenzo, BS VIII 108-121.

32 Por. notatki do wykładu instalacyjnego, dz.cyt., VII 453; wiersze: 228-2.30, 271-272, 289, 422-425, 438-439, 510-511 oraz sparafrazowane 352-356.

33 Wykład instalacyjny, dz.cyt., VII 342: Słowa te saz najbardziej zblizone do następującej strofy z "Peristephanon" II 353-356, CCL 126,269, przekład Brożka:

"Wstepuj na stos ten zasłany

Na godnym kładź się łózeczku,

A potem jak chcesz rozprawiaj,

Że nic nie znaczy mój Wulkan". 
równiez inne informacje znane sobie z literatury martyrolorieznej. Następnym męczennikiem, któremu poświęca lickiewicz nieco uwagi, Jest św. Hipolit. Poeta przytacza we wasnym txumaczeniu fragment z XI "Wieńca", " którym znów na plan pierwszy wysuwa się cyniczna 1 bezduszra postać prokonsula:

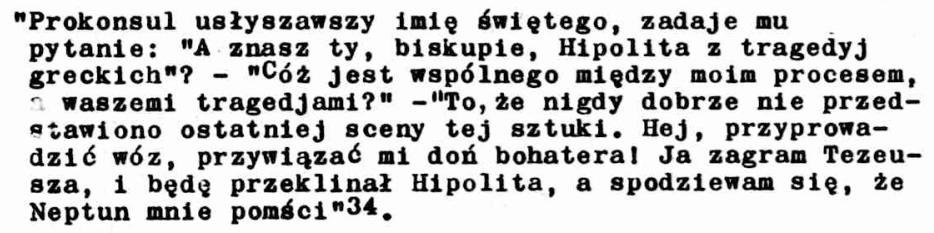

Snderć męczennika Mickiewicz skomentował jednym, ale jakze wymownym zdaniem: "Urzeczywistnił okrutny zart śród oklasków publ_czności"35. Odtworziony dialog jest dość odległa parafraza, majaca więszą podstawe raczej w tekście jakiejś starozytnej tragedi1 ${ }^{36}$, cie Prudencjusza. Najbardziej zblizony jego fragment odpu piadając opisowi Mickiewicza, stanowia wiecsze $85-90^{37}$, wtórych jak to widać z przekładu Brokka ${ }^{38}$, ni, ma wzmianki ani o Tezeugzu, ani o Neptunie. Poeta hiszpański opisuje $\mathbf{w i c h}$ przywiązymanie męczennika, a walszej części utworu - jego śmjzré 1 pogrzeb. Nie wiadomo jednak dokładnie, o którego Hipolita Prudencjusz. 1 chodziło, czy o biskupa Antiochi1, umęczonego w IV w. 1 wspominanego przez starozytne

34 Wykład instalacyjny, dz.cyt., 343 .

35 Tamze.

36 Według mitologil greckiej mityczny król Aten, Tezeusz, podejrzewając syna Hipolita o miłostki z zona Fajdra, macocha chłopca, rzucil na niego przeklenstwo, które uszyszal Neptun 1 wyskal potwora, by spłoszył konie prowadzone przez miodzienca powodnjąo jego śmierć. Zarówno sam romans, jak 1 późniejsza śmier niewinnego młodzieńca by $ł y$ częstym przedmiotem tragedi1 greckich 1 rzymskich. Por. Eurypides, Hipolit; Seneka, Hipolit; Owidiusz, Heroidy IV $61 \mathrm{nn}$.

37 Wieniec XI 85-90, CCL 126, 372-373.

38 Przekład M.Brozka:

"Sędzia z zadartą do góry głowa pyta dumnie:

"Jakie jego $1 \mathrm{mie}$ ?" Lów1 a te Hipolit.

"Ach! To niech bedzie prawdziwym Hipolitem! Konie

Spłoszone 1 dzikie na śmiett go rozszarpial"

Ledwie to orzekł, juz dwójke źrebców nie znajacych

Wegdzid, a wprzegaja obce im uprzęzen" 
martyrologia /Martyrologium Hieronymianum, Martyrologium Syriacum, Martyrologium Romanum/ dnia 30 stycznia, czy o znanego prezbitera rzymskiego 1 antypapieza, umęczonego w 1. poł. III w., gdyż informacje o tych dwóch postaciach pod kontec IV w. wzajemnie się uzupełniały. Oglądał on, jak pisze, jego grób i czytał napisany przez Damazego epigram, który częściowo w swym poemacie parafrazuje, co wskazywałoby raczej na tego drugiego. Do tradycyjnych danych Prudencjusz dorzuca "swym "Wieńcu" niezname nam blizej szczegóły, pochodzazce prawdopodobnte z Passio Polychronil. Hipolit, według niego, miał być prezbiterem, który, po odwołaniu swych błędów, został podczas prześladowania oskarżony, a następnie skazany w ostii na śmierć przez rozdarcie końmi. Świadkowie męczeństwa zebrali jego szczątki 1 pogrzebali w Rzymie ${ }^{39}$. Również Mickiewicz nie rozstrzyga, o którego Hipolita chodzi, a moze nawet nie wie, ze było ich dwóch, ale opierając się wyłącznie na przekazie Prudencjusza wybiera z jego poematu przede wszystkim elementy dramatyczne, nieobce słuchaczom obeznanym z kultura klasyczną.

Helidoniusz - to kolejny męczennik wspominany przez Mickiewicza. I tym wypadku poeta nie opisuje jego mezceństwa, ale ogranicza się do ogólnego, obliczonego na obudzenie wzruszenta u słuchaczy, wprowadzenia o dziewicach 1 dzieciach;

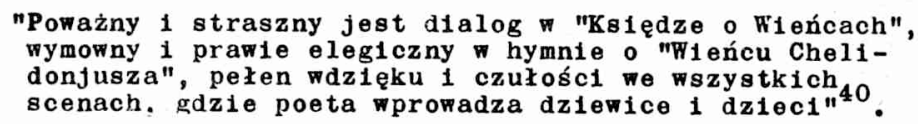

Okazuje się, że powyższa wzmianka Mickiewicza o dziewicach 1 dzieciach, o których jednak Prudencjusz przy opisie męczeństwa Emeteriusza i Helidoniusza nie wspomina, odnosi sie najprawdopodobniej do koŕcowego apelu z poświęconego im I "Wieńca"41, gdzie poeta hiszpański wzywa

39 Por. H.Achelis, Hippolytstudien/TU XVI 4/, Leipzig 1897, 1-62; G.Bovini, Sant'Ippolito dottore e martire del III secolo, Roma 1943; P.Sfair, Ippolito /Antiocheno/ oraz: A.Amore, Ippoilto Romano, BS VII $867,869-875$.

40 Wykład instalacyjny, dz.cyt., 343.

41 Wieniec I 118-120, CCL 126,256, przekład Brozka:

"Stójcio, matki, za maleństwa odzyskane dziękujciel

Tu głos żon niech szczę́́cien z męzów ocalenia rozbrzmiewa,

Niech nam dzień ten f́łį̨tem będzie, uroczystz radością)" 
matki do dziękowania Bogu za odzyskane maleństwa.

Głównym i najstarszym źródłem hagiograficznych informacj 1

o wspominanym przez Mickiewicza Helidoniuszu i nie wymienionym jego towarzyszu broni - Emeteriuszu jest Prudencjusz. Mieli oni pod koniec III w., prawdopodobnie podczas prześladowania Galeriusza /293-305/, porzucić wojsko i pójść za Chrystusem, za co zostali ́́cięci w pewnym mieście Guascogny ${ }^{42}$.

W miarę zbliżania się ku końcowi wykładu, Mickiewicz coraz bardziej go dramatyzuje przez umiejętnie dobrane cytaty. Przytacza po łacinie, bez podawanta lokalizacji, trzy nie zwiazane ze sobą kolejnością wybrane wiersze, opisujące pożegnanie i oddanie przez matkę na śmierć swego dziecka:

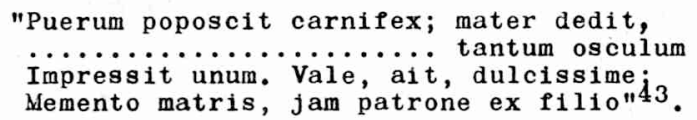

Okazיje sie, że jest to Pragment $x$ "Wieńca" Prudencjusza, poswıęcony świętemu Romanowi ${ }^{44}$, którego imienia Mickiewicz nie wymienıa. Polskiemu poecie nie chodziło bowiem o przekazanie słuchaczom wiadomości na temat starożytnego męczennika, ale znów o wywołanie dramatycznych efektów literackich przez odpowiedni zestaw cytatów.

Według sprawozdania dziennikarza lozańskiego, Mickiewicz urwał po słowach: "jam patrone ex fillo" - "z syna już mój patronie"

42 Por. Gregorius Turonensis, De gloria martyrum 93, PL 71, 786-787 /wskazuje na ich grób w katedrze w Calahorra/; Martyrologium Hieronymianum, ed. Delehaye /Commentarius perpetuus in Martyrologium Hieronymianum ad rec. H.Quentin/, Bruxelles 1931, 124 ; Martyrologium Romanum, ed. Delehaye, Bruxelles $1940,83=1 \mathrm{ch}$ święto 3 marca; A.Amore, Emiterio e'Chelidonio, BS IV, 1195-1197.

43 Wykład instalacyjny, dz.cyt., 344.

44 Wieniec X 831-835, CCL 126, 358-359, przekład Brożka:

"Kat żąda dzıecka 1 matka oddaje syna, N1e zwleka, nie płacze nad nim/ i tyiko jednym Żegnając go pocałunk1em mów1: "Najsłodszy,

Żegnaj!/A szczęśli /ry wszedłszy w Królestwo Chrystusa/ Pomnij swej matki - ty z syna juź mój patronie". 
1 usprawiedliwiz swoje wzruszenie mówiąc, ze słowa te przypomniały mu podobne męczeństwa wileńskie: "Darujcie at - powiedzia: - to waruszenie. Byłem swiadkiem podobnych rzeczy"45. Słuchaczy, ktirzy wiedzieli, ze lch Profesor pochodzi z umęczoneco narodu, 1 ze tego rodzaju sceny nie były mu obce, ogarnęło niewątpliwie wielkie xzruszenie. Wykładowca zaś podsumował cy iowany eragment słowami: "Napróznoby Panowie szukali tej czułości macierzyáskiej, tej prostoty patrjarchalnej stylu wajpiękniejszych dziez a starożtnosc1" ${ }^{46}$.

Mickiewicz nie zaznacza, skąd zaczerpnął cytowane wiersze lacińskie, a tym oardziej nie rozstrzyga, o którego ilomana tu chodzi - rzymskiego towarzysza męczeństiva św. Kuwrzyńca, czy o mnicha antiocheńskiego ${ }^{47}$, mimo iz męczennik o takim imieniu był popularny 1 czczony $w$ IV 1 V w, oraz stanowił przedmiot kazań kilku 0jców Kościoła ${ }^{48}$, ale Idże wiernie za Prudencjuszem, bez pogłębiania jego przekazu.

Apogeum enspresji osiagga Mickiewicz dr jero w ukazaniu męczeństwa sw. Eulalil. Poeta wyraza ubolewanie wopec słuchaczy, ze niniejszego wykładu nie rozpoczłłł od anal1zy hymnu poświęconego E: 111: "Już przepisując te wiersze, żałowałem, ze nie zacząłem od hymñu o míeńcu św. Eulali1" ${ }^{49}$. Postać tej męczenniczki, dwunastoletniej dziewicy umęczonej na początku IV w. za Maksymiana w hisz-

45 Por. Wł.Mickiewicz, Żywot, II 457.

46 Wykład instalacyjny, dz.cyt., 344 .

470 męczeństwie Romana, diakona antiocheńskiego, pisał najpierw Euzebiusz z Cezarei w traktacie "O męczennikach palestyńskich" /rozdz. 2, POK 3, 465-466/. Według jego wersji Roman został skazary nz spalenie na stosie, a gdy p tazas egzekucjl głośno wyznawał swz wiarę, obcięto mu język, po czym wtrącono do więzienia, gdzie zakuty $w$ dyby został uduszony. Lata przedmęczeńskie tego swiętego uzupełni? Prudencjusz szczegółami z nieznanych nam blizej źródeł o życî. Romana rzymskiego, tworząc w $X$ Wieńcu cały żyot jednegs Romana, który miał z ginąć za cesarza Galeriusza pod koniec iil w. Za wersja Prudencjusza poszły następnie Me yrologium Romanum i późniejsze Passiones. Por. H.Delehaye, S.I.main martyr d'Antiocie: Passio graeca anonima, AB 50/1932/241283; J.M.Sauget, Romano, BS XI / Toma 1:68/338-342.

48 Por. Joannes Chrysostomus, Homilia in s.Romanum, PG 50, 605-612; Eusebius Emesenus, Homilia de resurrectione, $P G$ 24, 1097; Severus Antiochenus, Homiliae $I, \lambda x . V, L X X X$, wygłoszone w kościele św. Romana w Antiochil, pierwsza - po koptyjsku/"Revue de lorient Chrétien" 19/1914/69-74, 135-142/, dwie ostatnie - po syryjsku /PO 20, 324-345/.

49 Wyklad instalacyjny, dz.cyt. $\quad \therefore 4$. 
pańskiej Meridzie 50 , była szczególnie bliska Prudencjuszowi. Pośmięcil Jej III "Wieniec", liczzcy 215 wierszy ${ }^{51}$, w którym opisuje bazylike nad jej grobem w Meridzie oraz jej zycie i męczeństwo. Zatroskany ojciec wynosi córkę z miasta na wieś, by ukryć já przeả prześladowcami. Ona jednak pragnąc męczeństwa, gardzi wszelkimi podarunkami, ucieka noca od ujca, staje przed pretorem 1 wyznaje swą chrześcijańska wiarę. Wzruszony sqdzia stara sie jzod tego odwiesć, ale wobec jej nieustępliwej postawy wydaje wyrok śmierci przez spalenle na stosie, co poeta niszpański szczegółowo opisuje. Relacja Prudencjusza stała się podstawa do powstania nie tylko późniejezej Passio tej świętej ${ }^{52}$, ale 1 poświł̨conych jej homilii przez kilku 0jców Kościoła 1 w ogóle żywota ${ }^{54}$.

50 Martyrologium Romanum wymienia dwie hiszpańskie męczennice - tym imieniu: św. Eulalięz Barcelosv umęczoną za Dioklecjana /mspomnienie $1<$ II/ 1 św. Eulalie z Lioridy umęczona za Maksymiana/wspomniente $10 \mathrm{XII} /$. Trudno dziśs rozetrzygnác, czy sa to dwie róźne postacie, czy teź chodzi o dwie relacje tego samego męczeństwa. Por. A. Fábrega Grau, Santa Eulalia de Barcelona: Revision de un problema historico, iloma $1958=$ ze sa dwie Eulalie, ale recenzent tej nonografii B. de Gaiffier /AB 77 /1959/196-198/ podważa te hipoteze. Nie ma jednak wątpliwości odnośnie do historyczności przynajmniej jednej mǫczennicy, znanej nawet poza Hiszpania, gdyz wspominaja ją liczne źródła, jak: Martyrologium Hieronymanum, Martyrologium Carinaginiense $z$. poł. VI w.., inskrypcja z Béziers/E.Diehl, Inscriptiones Christianae Latinae Veteres, I, Berlin 1923, n. 1807/, inskrypcja $z$ Meridy /J.Vives, Tnscripciones cristianas de la España romana y visigoda, Barcel: onc 1942, n.348/, moza'ka z S. Apollinare Nuovo $w$ Rawennie z poł. VI w. przedstawiajaca Eulalie z inzymi dziewicami oraz hiszpańskie 1 mozarabskie księgi liturgiczne wspominajace jaz 10 grudnia.

51 Wieniec III /Hymnus in honorem passionis Eulaliae beatissimae martyris, CCL 126, 278-285.

52 Akta męczeńskie Eulali1 zaginęły prawdopodobnie jeszcze przed Prudencjuszem, późniejsza zaś jej Passio powstała prawdopodobnie w VII w. /BHL I 2693-2703/.

53 Por. Sermo S.Augustini, in: D.Morin, Miscellanea Agostiniana, I, Roma 1930, 593-595; Gregorius Turonensis, De gloria martyrun 91, PL 71, 785 .

54 Por. V1es de saints, XII 312-316; Z.Garcia Villada, Historia Ecclestástica de España. I, Madrid 1929, 282-300; A.Fábrega Grau, Passionario hisp nico, I, Madrid-Barcellona 1953, 78-86; tenze, DHGE XV 1380-13iu; M.Sotomayor, Eulalia, BS V 204-209. 
Już z góry można było przewidzieć, że tego rodzaju żywot, opowiadajacy o śmierci niewinnej pięknowłosej dziewczynki palonej na stosie 1 broniącej swoich przekonań, dogłębnie wzruszy Mickiewicza, a w sposób umiejętnie przedstawiony pochłonie bez reszty uwage słuchaczy. W oparciu o fabułę Prudencjusza, charakteryzując postać męczennicy Mickiewicz streszcza pewne partie hymnu, Inne zaś cytuje po łacinie skandując je w starożytnym metrum:

"Dzieweczka ta miała rodzinę bogatą 1 potęzną, lecz od najdrobniejszego wieku była powazna, 1 dzieci nazywały ją stolczka; ich zabawk j jej nie rozweselały:

Ipsa crepundia reppulerat, Ludere nescia pusiola, Spernere succina, elere rosas, Fulva monilia respuere ${ }^{55}$. Turbida Prangere beila parat ${ }^{56}$.

Rozgniewany prokonsul nakazuje katom spełnić powinnosć. Ci uderzaja Eulalie zapalonem łuczywem. W jednej chwili ogień chwyta się jej długich $i$ bujnych włosów, płomień ogarnia głowe i wzbija się słupem z czoła, jak z ołtarza. Swięta dziewica wdycha silnie płomień, pije go łakomie:

"Appetit et bibit ore rogum" 57 1 wyprózniwszy ten kielich świetlisty, oddaje ducha. ogień gaśnie równocześnie:

Colla fluunt abeunt, anima,

Et rogus igneus emoritur 58 ? Prokonsul zamyka posiedzenie 1 usuwa się wzruszony. Kac1 oddalaja się zdumieni. Tłum rozprasza się, a pośrodku placu zostaje trup w swojej surowej nagośc1. Szczęśliwie chmura zatrzymała się, rzuciła sniegiem 1 nakryła ciało białym całunem:

55 Wieniec III 19-22, CCL 126, 278-279, przekład Brożka:

"Bo nawet zabawki odtrąc1ła swe,

Choć maleńka jeszcze nie chciała $1 \mathrm{ch}$ znać,

Bursztynów nie chciała ni radości z róz, Odrzucała złotych naszyjników zwój".

56 Tamż, 32-33, CCL 126,279, przekład Brożka:

"Serce zapalczywe gotuje się w niej

Do złamania tego niepokoju burz".

57 Tamze, 160, CCL 126, 283, przekład Brożka:

"Eulaila stos wdycha 1 chłonie do płuc".

58 Tamże, 166-167, CCL 126,283, przekład Brożka:

"Gdy dusza odeszła, szyja skłania się, Zamiera tez zwolna cały ognia stos". 
Pallioli vice linteoli 59 .

Takiej przyzwoitości 1 - ośmiel ż się powiedzieć szanowności wysłowienia, delikatności uczucia i prostoty patrjarchalnej próżnoby szukać u autorów starozy tny ch" 60 .

Można sobie wyobrazić, ze przytoczone wyzej eragmenty Prudencjusza, cytowane $z$ odpowiednim komentarzem przez poetę pochodzącego $z$ unęczonego kraju, mogły w pełni zainteresować słuchaczy poezja wczesnochrześcijańską.

Z powyższych danych wynika, że głównym a niekiedy jedynym źródłem wiadomośc1 o męczennikach wozesnochrześcijańskich była dla Mickiewicza poezja Prudencjusza, a szczególnie jego poemat "0 wieńcach". Wybierajqc z niej niektóre postacie męczenników Wawrzyniec, Helidoniusz, Hipolit, loman, Eulalia/ nie zamierzał on bynajmniej pogłębiać lub obszerniej przedstawiać ich żywotów, ale jako poeta szukał w nich przede wszystkim artystycznych środków wyrazu i dramaturgii, którymi mógł wzruszać, zachwycać 1 przykuwać uwage swych słuchaczy. Czyż mógł ktoś lepiej od Mickiewicza, dotkniętego osobiście 1 przeżywającego boleśnie męczeńskie dzieje umiłowanego narodu polskiego, zrozumieć ofiarę z życia starożytnych chrześcijan w obronie bliskich im wartości? Szkoda więc, że jego wykłady o chrześcijańskich bohaterach pozostały tylko w sierze projektu.

\section{Alicja Stępniewska - Lublin}

\section{LES MARTYRS PALEÓCHRÉTIENS \\ DANS LES CONFÉRENCES LAUSANNOIS ES D'ADAM MICKIEWICZ /Résumé/}

Dans la première partie de l'article, l'auteur groupe soigneusement tous les énoncés d'Adam Mickiewicz, le plus grand poète polona1s, concernant l'antiquité chrétienne; dans la deaxième, ollo analyse on détall ce que Mickiewicz disalt à propos des martyrs pa-

59 Tamże, 180, CCL 126,284, przekład Brozka: "Jak pod prześcieradłem i płótnami z lnu".

60 Wykład instalacyjny, dz.cyt., 344-346. 
léochrét1ens. Il en parlait surtout pendant ses conférences lausannoises /1839-1840/, et particulierement, dans son cours d'installation/26 VI 1840/, où 1 l décrivalt la poessie de Prudence. Entre 14 héros ohrétiens caractérisés dans "Peristephanon" de Prudence, M1ckiewioz ohoisit 5/, salnt Laurent, Célldonius, Hippolyte, Romain

Eulalie de Méride/ et les présente plus soigneusement. Il ne tâche pas, quand meme, d'approfondir les informations données par Prudence, mals en tant que poète, 11 cherche surtout dans la vie des martyrs les effets dramat1ques et artistiques. 